\title{
Ethnobotanical, phytochemistry, and pharmacological property of Waltheria Indica Linn
}

\author{
C Nirmala ${ }^{*}$ (1) and M Sridevi
}

\begin{abstract}
Background: In modern therapeutics, various human pathological disturbances were treated with the plant-based products. Waltheria indica Linn, a perennial herb, was commonly used in traditional medicine worldwide against various ailments such as cough, dysentery, diarrhea, bladder disorder, hemoptysis, inflammations, neuralgia, wounds, and ulcers.

Main body: The shrub was majorly distributed in tropical, subtropical regions and exists in many distinct local forms. Both the crude extracts and purified compounds from the whole plant and its parts showed wide pharmacological properties like antioxidant, analgesic, sedative, anti-bacterial, anti-fungal, and anti-parasitic. The phytochemical profile and traditional usage highlight the potency of the plant in the treatment of microbial infections and inflammatory diseases. Yet, additional studies are required for the confirmations of its traditional uses against other diseases. More detailed understanding of anti-cataract, anti-diabetics, asthma, anemia, and anti-cancer mechanism has to be explored. Though many research articles on the proposed plant are available, there has been a rising concern in the therapeutic property, especially on the alkaloids and flavonoids from this plant for drug design.

Conclusion: This article aims in a systematic and updated review on distribution, botany, traditional uses, phytocompounds, and relevant biological activities from each part of the plant. The information was collected from databases like PubMed, ScienceDirect, Web of Science, Google Scholar, books, dissertation, and reports via academic libraries that included more than 100 articles published since 1937. This ethnopharmacological study of the plant may create new insight into drug discovery to develop important novel leads against various biological targets.
\end{abstract}

Keywords: Waltheria indica, Distribution, Traditional uses, Phytochemicals, Pharmacological activities

\section{Background}

In both developed and developing nations, the majority of the population relies on plant-based traditional medicine to overcome high resistant pathological conditions and new emerging diseases [1]. Plants contain various bioactive compounds that give them therapeutic

\footnotetext{
* Correspondence: nirmalabt@gmail.com

Department of Biotechnology, Vinayaka Mission's Kirupananda Variyar Engineering College, Vinayaka Mission's Research Foundation (Deemed to be University), Sankari Main Road (NH-47), Periyaseeragapadi, Salem, Tamilnadu 636308 , India
}

potency. According to the World Health Organization (WHO), plants represent the best sources for obtaining a wide variety of drugs that could benefit a large popula[2]. Only $10 \%$ of plant species available worldwide knowledge of plants is also disintegrated [5]. It is imperative to document traditional usage and medicinal property of every plant species and their products for 
better understanding by rural communities and new drug development.

Waltheria indica, a medicinal plant commonly known as sleepy morning, is distributed widely in tropical regions of the world. The plant has bitter, cool to cold, and astringent property; hence, it is used to clear damp heat, poison and to cool blood. It is also utilized by native populations in different regions of the globe to treat several pathological conditions. The nutrient constituents like caffeic acid, flavonoids, alkaloids, sugar, and tannins are identified in the whole plant extracts that contribute to the medical applications [6].

Based on the etic approach, evidence on the pharmacological property of $W$. indica are available [6-9]. Still, anti-cataract [10], anti-diabetics [11], asthma [6], anemia [12], aphrodisiac [13], and anti-cancer activity [14] have to be evaluated for a detailed understanding of its mechanism and to utilize them in new drug designing process. This review aims to present an updated overview of the conventional use, medicinal properties of crude extract, and isolated phytocompounds from $W$. indica. The article also reviews the emic perspective of local and traditional uses of $W$. indica at different parts of the world. The growing interest in the curative properties of the plant evoked to review the previous studies on the plant extracts and its bioactive compounds for novel pharmacological preparations. This discussion may justify future research opportunities for this plant to promote the development and expansion of plantbased medicine.

\section{Main text}

\section{Research data extraction criteria}

The data acquainted for the study was browsed from PubMed, ScienceDirect, Web of Science, Google Scholar, books, dissertation, and reports via academic libraries. The data were retrieved using the terms Waltheria, pharmacological property of W. indica, and W. americana that was published since 1937. The search was solely performed on data reporting pharmacological, chemical, and experimental studies on in vitro and in vivo models, using the isolated compounds and crude extracts from the proposed plant. To grant reliability on data publications information from peer-reviewed journals are alone chosen.

\section{Geographical distribution}

The shrub, $W$. indica, is distributed majorly in subtropical and tropical zones of scrub forests, moist deciduous forests, plain grasslands or woodlands, rocky hills, gravelly soil, humid sandy soils, clay soils, riverbanks, savannahs, and in disturbed or impoverished soils. The plant is indigenously distributed in East Africa [15], West Africa [16], Northern part of South Africa covering
Namibia and Botswana [7, 17], Hawaii [18, 19], South America $[8,20]$, tropics, and subtropics of the old and New World covering Florida and Texas to Brazil [21-23]. In India, the plant is widely distributed in Punjab, Gujarat, Maharashtra, Assam, Odisha, Andhra Pradesh, Tamil Nadu, and Kerala [24, 25]. The plant is confined to the mineralized ground with a high concentration of zinc, copper, manganese, rubidium, strontium, sodium, and potassium [26].

\section{Taxonomic classification \\ Domain: Eukaryota \\ Kingdom: Plantae \\ Phylum: Spermatophyta \\ Subphylum: Angiospermae \\ Class: Dicotyledonae \\ Order: Malvales \\ Family: Sterculiaceae \\ Genus: Waltheria \\ Species: Waltheria indica Linn \\ Synonym: Waltheria americana}

Waltheria, the genus name was given in credit to Augustin Friedrich Walther (1688-1746), the German anatomist, botanist, and physician and 60 species were included under this genus [27]. Fosberg and Sachet [28] stated that $W$. indica and $W$. americana are reported simultaneously. The dense hairy form of W. indica var. indica; var. americana and thin pubescent form of var. indica was proposed by Robert Brown [29]. Hence, $W$. indica exists in many local forms that are distinct from other characters, without influencing taxonomic identification [28].

\section{Vernacular names}

The plantae is commonly known as velvet leaf, monkey bush, marsh-mallow, boater bush, buff coat, and leather coat [30]. The epithet indica links the species with India, hence known as 'Nallabenda' in Telugu, 'Shengalipoondu' in Tamil [31]. In northern Nigeria, the plant is locally called as 'kafafi' in Fulani, 'hankufah' or 'hankubah' in Hausa, 'efu-abe' in Nupe, 'korikodi' in Yoruba [32, 33], 'matum kevel' in Wolof [34], 'kiaza' or 'kerza' in Bissa [35] 'yar-yamde' in Moore [36], and 'Mokhutesela' in Limpopo province in South Africa [37]. Also, it is named 'güinar,' 'manrubio o tapacola' in Mexico [34], 'hierba de soldado' in Panama, 'barulad' in the Philippines [38], 'hi'aloa,' 'uhaloa,' 'kanakaloa,' 'mauvegris,' 'motobranco,' 'fulutafu,' and 'kafaki' in Hawaii [39]. The Spanish common names of the plant are 'basoraprieta,' 'escobilloblanco,' and 'malvavisco' [40]. Though the plant has many local names, the scientific research and reports are presented in two Latin names $W$. indica and W. americana. 


\section{Botanical description}

W. indica, a flowering plant species (Fig. 1) in the Malvaceae family, was placed previously in family Sterculiaceae. It grows in areas receiving annual rainfall of about $750-1800 \mathrm{~mm}$ and at $400 \mathrm{~m}$ (1300 ft) elevations from sea level. It is an erect, hardy, short-lived, spreading subshrub reaching 2-7 $\mathrm{m}$ height with a stem diameter of $2 \mathrm{~cm}$. The plant develops a brown, flexible, weak tap root, strong lateral roots, and enormous fine roots. It has a strong, single stem that often branches near the ground. The grayish-green leaves of the plant are alternate, egg-shaped, and narrowly ovate with a round to heart-shaped base, zigzag serrate edges, and rounded to pointed tip [41]. The stalks are $0.5-3.3 \mathrm{~cm}$ long; the blades are 2-12 cm long and 1-7 cm broad. Thick inflorescence clusters are found in leaf axils, which contain fragrant, yellow to orange flowers that appear throughout the year. The flowers have 3 bracts and a cup-like green calyx of 2-4 $\mathrm{mm}$ long that become brown on aging. Five yellow petals of $4-5 \mathrm{~mm}$ long fused at their base with 5 stamens that turns reddish-brown at maturity. Each $2 \mathrm{~mm}$ capsule of the fruit encloses one tiny, black, obovoid seed in the calyx cup until becoming

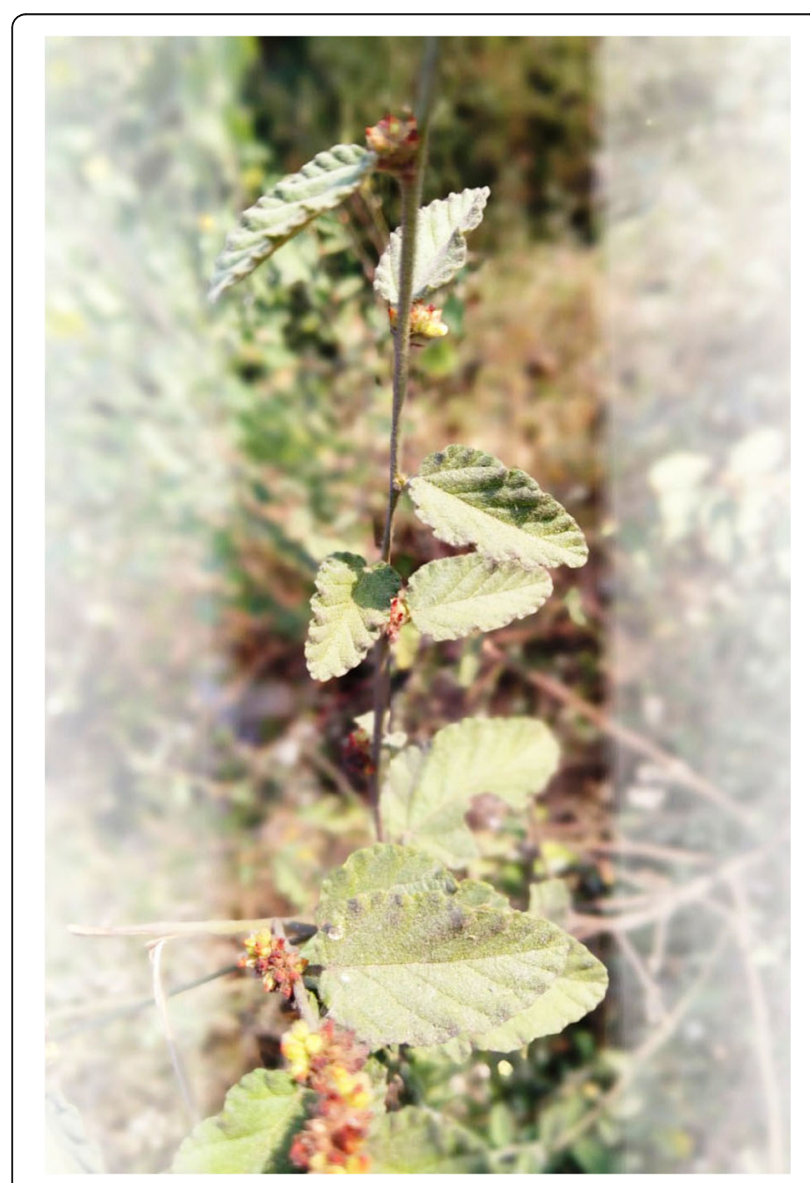

Fig. 1 Waltheria indica Linn brown and dry. This shrub species have 1 locule ovary that differentiates from other species of Malvaceae that have 2 or more locules [42].

\section{Phytochemical screening}

The phytochemical analysis of the perennial plant W. indica showed the presence of different chemical groups like flavonoids, alkaloids, terpenes, sterols, tannins, cardiac glycosides, saponins, anthraquinones, and carbohydrates (Table 1) at various degrees in the whole plant $[9,11,43,53]$.

The pharmacological activity of the plant relies on the presence of various bioactive compounds (Fig. 2). Pais et al. [54, 55] identified and named alkaloids in the leaves and roots as adouetins $\mathrm{X}, \mathrm{Y}, \mathrm{Y} 1$, and $\mathrm{Z}$ which were considered as the first reported cyclopeptide alkaloids in plants. From the whole plant, flavonoids like epicatechin, kaempferol derivatives, tiliroside, and quercetin were reported [51, 56, 57]. 5,2',5' -trihydroxy-3,7,4' ${ }^{\prime}$-trimethoxyflavone and 5,2'-dihydroxy-3,7,4',5'-tetramethoxyflavone were isolated from leaves [59]. 2,3Dihydro-3,5-Dihydroxy-6-methyl-4h-pyran-4-one, tetradecane, tetracosane, nonadecane, squalene, and phytol are the major bioactive compounds identified in the ethanolic extracts of leaves [60]. From the dichloromethane extract of aerial parts, polyhydroxymethoxy flavonoids such as vitexicarpin, flindulatin, oxyanin A, chrysosplenol E, 5-hydroxy-3,7,4'-trimethoxyflavone, and quinolone alkaloids, like Waltheriones A, C, E-L, M$\mathrm{Q}(2,7,8,10,11)$, and $5(\mathrm{R})$-vanessine were identified. Novel compounds like Methyl (2R,3R)-3,4-dihydro-3,8dihydroxy-2-methyl-(4-methylpent-3-en-1-yl)-2H-1-benzopyran-6-carboxylate, Methyl(R)-2,3-dihydro-7-hydroxy -2-[(S)-2-hydroxy-6-methylhept-5-en-2-yl]-2H-1-benzofuran-5-carboxylate, Methyl(R)-2,3-dihydro-7-hydroxy2-[(2R,5S)-5-(2-hydroxypropan-2-yl)-2 methyltetrahydro furan-2-yl]-2H-1-benzofuran-5-carboxylate, (2S)-2-[(1S)1-(5,5-Dimethyltetrahydrofuran-2-yl)-1-hydroxyethyl]-2, 3-dihydro-2H-1-benzofuran-5-carboxylic acid, and Methyl (2S,4aR,10aS)-2,3,4,4a,10,10ahexahydro-6-hydroxy2-(2-hydroxypropan-2-yl)-4a-methyl-pyrano[3,2-b][1]ben zopyran-8-carboxylate were also identified in aerial parts of the plant $[14,52,61]$.

\section{Traditional uses}

Each part of the plant and its infusions are traditionally used for the treatment of cough [15], eye baths [15], ulcers [20], hemoptysis [8], bladder ailments [38], neuralgia $[43,62]$, and lung infections [62]. It is applied externally to cure skin diseases like skin eruptions [38], wounds [34], abscess, and leprosy [8]. The plant is also used to medicate diarrhea [47], rheumatism [20], epilepsy [34], aphrodisiac, impotence [46], malaria, typhoid fevers [63], and tiredness [48]. In Turks and Caicos Islands, the herb tea and the plant extracts are used as 
Table 1 Phytochemical constituent in different parts of $W$. Indica

\begin{tabular}{|c|c|c|c|}
\hline S. & $\begin{array}{l}\text { Plant } \\
\text { parts }\end{array}$ & Phytochemical constituents & References \\
\hline 1. & Roots & Alkaloids, carbohydrates, cardiac glycosides, saponins, steroids, tannins & {$[8,43-46]$} \\
\hline 2. & Stem & Alkaloids, carbohydrates, cardiac glycosides, saponins, steroids, tannins & {$[8,39,43,44,46,47]$} \\
\hline 3. & Leaves & Alkaloids, carbohydrates, cardiac glycosides, phenolic acids, saponins, steroids, tannins, terpenoids & {$[8,43-50]$} \\
\hline 4. & Flowers & Alkaloids & [39] \\
\hline 5. & Aerial parts & Caffeic acid, flavonoids & {$[51,52]$} \\
\hline 6. & $\begin{array}{l}\text { Whole } \\
\text { plants }\end{array}$ & $\begin{array}{l}\text { Alkaloids, anthraquinones, carbohydrates, cardiac glycosides, flavonoids, mucilage, saponins, sterols, } \\
\text { tannins, terpenes }\end{array}$ & $\begin{array}{l}{[8,9,11,43,44,46,47,} \\
53-58]\end{array}$ \\
\hline
\end{tabular}

curative for female sterility. Formerly, the fiber from the plant was used for producing cords, sacking, sandals, and padding [43]. The stems are used as a chew stick [58]. In Hawaii, to ease sore throat, the root is chewed [64]. The root bark decoction and the whole plant are used as a bitter tonic for adults against asthma [36]. Stems and leaves are used as a blood tonic, an immune booster, and for strengthening young children [30]. The Fulani group uses the root aqueous extract for treating internal hemorrhage, syphilis, and relieving pains and aches. It is also used as a restorative agent during the labors of harvesting by the Yorub $[46,65]$.
The whole plant combats various infant illnesses; specifically, the yellow flowers and buds are used for infants during teething by Hausas community in northern Nigeria. The plant is also used as an abortifacient in Ghana [30], emollient in Haiti [66], purgative in South Africa [67], and sudorific in Venezuela [27]. In the Kalrayan hills of India, the plant is used to cure diabetes mellitus [11].

\section{Therapeutic properties}

On literature review, the suggested plant was found to have various pharmacological properties. Figure $3 a, b$

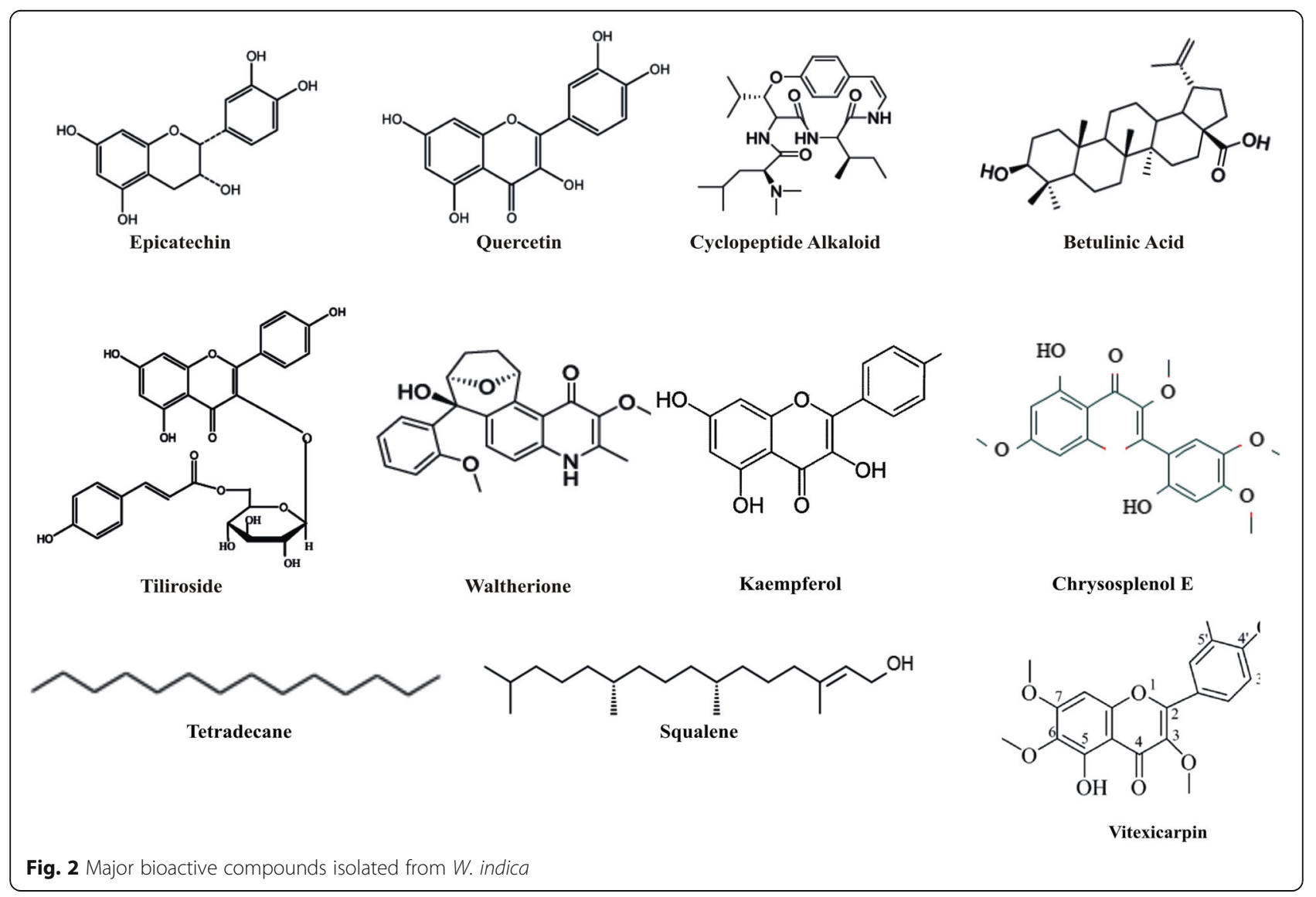




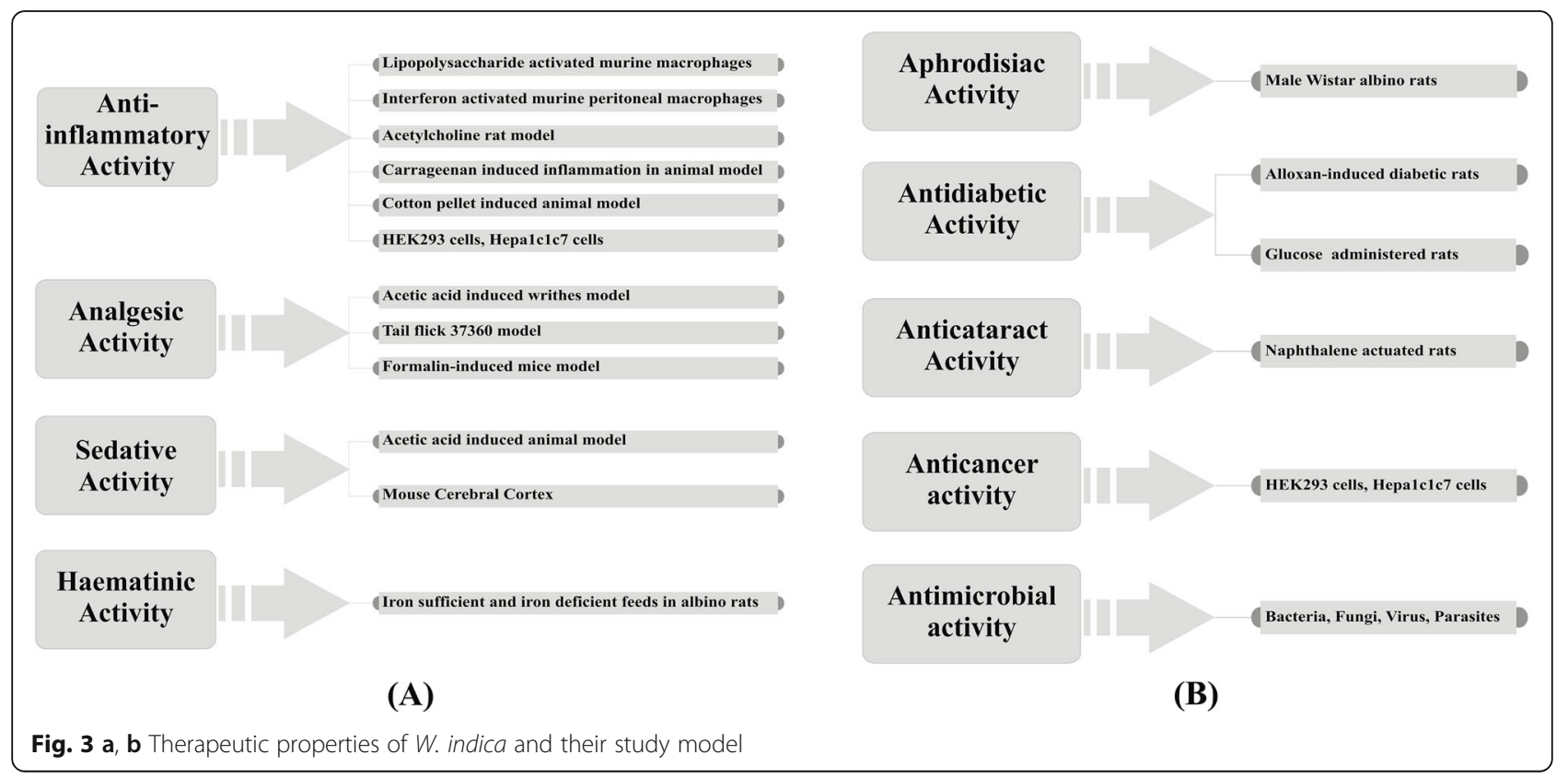

enumerates the therapeutic activities of the plant and their study model reported till date.

\section{Anti-inflammatory activity}

Inflammation is a complex biological response of body tissues for self-protection against irritants or pathogens. Flavonoid derivatives such as tiliroside, (-)-epicatechin, and quercetin obtained from sequentially fractionated ethanol whole plant extract were evaluated by Rao et al. [56] in lipopolysaccharide and interferon activated murine peritoneal macrophages. The results showed the inhibition of the inflammatory mediator cytokines, tumor necrosis factor (TNF)- $\alpha$, nitric oxide (NO), and interleukin (IL)-12, dose independently, without any cytotoxicity. Among the three flavonoids, quercetin exhibited high activity that may be due to its inhibitory effect of iNOS enzyme expression. Quercetin also inhibited protein tyrosine kinase that suppresses the cell signalling kinase Cdk2 [68]. Zongo et al. [6] interpreted that root extract and (-)-epicatechin isolated from root extract showed inhibition of smooth muscle contraction phosphodiesterase-4A1 (PDE4A1 $\alpha$ ), lipoxidase and phospholipase A2. The root extract also reduced the contractions induced by acetylcholine on isolated rat trachea. At the second phase of carrageenan inflammation in rats, high inhibition of edema is induced by the hydro alcoholic extract $(1 \mathrm{~g} / \mathrm{kg})$ of the whole plant of $W$. indica than phenyl butazone [69]. Pet ether, methanol leaf extracts of the $W$. indica, and aqueous extract of stems with leaves also showed dose-related inhibition of acute and chronic inflammation in Carrageenan induced edema. The effect may be due to inhibition of histamine, serotonin, bradykinin, prostaglandin, and cyclooxygenase
(COX) products $[9,70,71]$. Significant reduction in the pellet weight of cotton pellet granuloma test models was also observed after treatment with methanolic leaf extracts [71]. Nuclear factor (NF- $\kappa B)$, a key player in inflammation-induced tumor formation, was proved to be inhibited by Waltherione $\mathrm{A}$ and $\mathrm{C}$ obtained from the decoction of the aerial parts [14]. Hence, the property of selected plant in traditional treatment of inflammatory diseases is validated in both in vitro and in vivo studies.

\section{Analgesic activity}

Anti-inflammatory drugs are used as analgesics for pain treatment, but due to its side effects, traditional medicinal plants with analgesic properties are used nowadays. The analgesic property of $W$. indica aqueous root extract significantly reduced the abdominal constrictions in Swiss albino mice induced by acetic acid writhes than the stem extracts [46]. Hamidu et al. [72] conferred the highest protection in acetic acid induced-writhes by aqueous ethanolic plant extract (69\%) than N-butanol (54\%), acetone $(50 \%)$, and aqueous residue (38\%). The extract fraction protected the animal from death by increasing the amylobarbitone sleeping time. YougbareZiebrou et al. [9] showed that different concentrations of plant extracts had significant analgesic effects and dosedependent inhibition percentages at $300 \mathrm{mg} / \mathrm{kg}$ by weight of extract that was greater than the paracetamol (150 $\mathrm{mg} / \mathrm{kg}$ by weight). The anti-nociceptive activities were also analyzed in tail-flick, formalin-induced paw licking, and acetic acid-induced writhing tests in mice using methanol leaf extracts of the plant that indicated the reduction in the mean of the number of abdominal constrictions in the test groups compared to the control 
group [71]. Thus, these studies support the use of $W$. indica as an analgesic, anti-convulsant, and antinociceptive agents.

\section{Sedative activity}

Phytomedicine is found to be a better alternative for neurological disorders that acts harmlessly compared to conventional psychotropic drugs. General screening of $W$. indica revealed the presence of certain flavonoids and caffeic acid, which acts as a central nervous system sedative, medulla stimulant, and used to treat neuralgia. Blanpin et al. [73] explored that adouetin Z have sedative effect in mice with a reduction of spontaneous motor activity. The aqueous ethanol extract of the plant exhibited anti-convulsant and sedative actions by blocking leptazole-induced convulsion. The sleeping time of amylobarbitone sodium increased dose-dependently $(p<$ 0.05 ) and decreased exploratory activity in mice [72]. Various extracts of the leaf dose-dependently delayed the convulsion onset, convulsion death, and also reduced the number of convulsion per minute [74, 75]. Mundo et al. [76] showed that in mouse cerebral cortex, the wild plant and cell suspension cultures of $W$. americana increased the release of Gamma amino butyric acid (GABA), the neurotransmitter that may impose a positive effect on neuronal disorders like anxiety, depression, and dementia. Thus, the studies prove the neuropharmacological activity of plant extracts.

\section{Anti-bacterial activity}

Microorganisms contribute to various infectious diseases in humans like respiratory illness, diarrhea, and dysentery. A series of in vitro studies using different extracts of the same parts and different parts of $W$. indica were performed on the same and different microbial species. Diverse inhibitory properties were observed on the same microbial species based on the solvent extracts and plant parts. This may be due to variation in the presence of active compounds such as tannins, flavonoids, alkaloids terpenoids, steroids, and saponins in different solvent extracts. The leaves had the highest activity against Escherichia coli, Pseudomonas aeruginosa, and Salmonella typhi compared to the stem that may be due to the presence of cardiac glycosides in leaves [47, 77]. While the ethanol extracts from the leaf, stem, and root were active against both Gram-negative and Gram-positive organisms in the order of root extract $>$ stem extract $>$ leaf extract. This antiseptic activity may be due to the presence of phenolic compounds and their derivatives [8]. The aqueous, ethanol, methanol, and acetone extracts were tested against Bacillus pumilus, Enterococcus faecalis, E. coli, Shigella dysenteriae, Staphylococcus aureus, and found aqueous extract had good minimal inhibition concentration (MIC), and the zones of inhibition were dose- dependent [37, 58, 78]. One hundred milligrams per milliliter of root methanolic extract had $91.7 \%$ antibacterial activity against the clinical isolates (Klebsiella pneumonia, P. aeruginosa, S. aureus, Staphylococcus epidermidis) obtained from diabetic wound infection [79]. The leaf extracts in different polar solvents (acid, base, neutral polar, and non-polar) and root extracts (ethyl acetate, chloroform, and chloroform: methanol) showed the zones of inhibition between $24-28 \mathrm{~mm}$ and $24-25$ $\mathrm{mm}$, respectively, against $S$. pneumonia, S. aureus, $K$. pneumonia, S. pyrogens, and few Candida species [50, 80]. The anti-bacterial activity of the plant extract against Chlamydiae and Mycoplasma known to be used in treatment of conjunctivitis [29]. The mechanism of the anti-bacterial spectrum thus aligns with the bouquet of phytoconstituents in the plant. Hence the findings support that the plant can be used to treat urinary tract infection [78] and as an anti-bacterial, anti-diarrheal agent [81].

\section{Anti-fungal activity}

The frequency of multidrug-resistance fungal infections especially in immune-compromised patients is increasing with a mortality rate greater than $50 \%$ despite the development of new drugs. Flavonoids $\left(5,2^{\prime}, 5^{\prime}\right.$-trihydroxy-3,7,4'-trimethoxy flavone and 5,2'-dihydroxy-3,7, $4^{\prime}, 5^{\prime}$-tetramethoxy flavone) isolated from chloroform extract of $W$. indica leaf and quinoline alkaloids isolated from the roots inhibited the growth of Candida albicans, Candida krusei, Candida tropicalis, C. glabrata, C. parapsilosis, Trichophyton mentagrophytes, and Aspergillus niger $[50,59,80]$. The anti-fungal activities were $\mathrm{pH}-$ dependent that may be due to the changes in the fungal environment or protonation of the phyto molecules that facilitate their import into the fungal cells [82]. The results thus support the indigenous claim for the ethnomedical applications of $W$. indica as anti-fungal agents.

\section{Anti-viral activity}

The high prevalence of viral infections and the constant evolution of resistant viral strains lead to the development of novel anti-viral agents from medicinal plants. The hydro alcoholic and aqueous extract of the plant was analyzed against rotavirus, the causative agent of gastroenteritis, on its early replicative cycle and observed that the extracts decreased genomic RNA and viral protein synthesis [83]. The aqueous and methanol extracts showed significant inhibition on human immunodeficiency virus (HIV 1) protease [84]. The water-methanol shoot extract also inhibited HIV 1 (strain IIIb) and HIV 2 (strain ROD) [85, 86]. Herpes simplex virus, Semliki forest virus, vesicular stomatitis virus, and Coxsackie virus were not inhibited by the plant extracts [29]. The anti-viral property may be due to the presence of 1 - 
Docosanol, a broad-spectrum anti-viral agent active against lipid enveloped viruses that were identified in the ethanolic extract of the plant [60]. These results suggest evidence for the anti-viral activity of the plant.

\section{Anti-parasitic activity}

The emergence and spread of drug-resistance parasites attributed to the increasing prevalence of diseases. Phytoconstituents are now directed for the development of broad, chemically diverse anti-parasitic agents. Dichloromethane extract from roots and aerial parts of W. indica exhibited moderate anti-plasmodial activity [63]. Maregesi et al. [86] reported that the water-methanol (80\%) shoot extract showed anti-plasmodial activity with $\mathrm{IC}_{50}$ between 125 and $250 \mu \mathrm{g} / \mathrm{mL}$ [6]. Bala et al. [65] found the inhibitory activity of polar ethanolic whole plant extract against Trypanosoma brucei brucei (T. b. brucei) was higher than nonpolar petroleum ether extracts. Cretton et al. [61, 82] tested dichloromethane root extract against T. cruzi, T. b. brucei STIB 427 strain and T. brucei rhodesiense STIB 900. The highest activity was against $T$. cruzi with $\mathrm{IC}_{50}$ of $0.74 \mu \mathrm{g} / \mathrm{mL}$ and a good selectivity index value of 35 . Waltherione $\mathrm{C}$, an alkaloid fractionated from this extract exhibited low cytotoxicity ( $\left.\mathrm{IC}_{50}-101.23 \mu \mathrm{M}\right)$, anti-trypanosomal activity towards $T$. cruzi $\left(\mathrm{IC}_{50}-1.93 \mu \mathrm{M}\right)$ and a selectivity index value of 52 .

The mechanism of trypanocidal action is not clearly known, yet the presence of quinolone alkaloid, oleanane skeleton, and pentacyclic triterpenes from the plant extracts may lead to anti-trypanosomal activity. The activity of the extracts may be due to the interference in the redox balance of the parasites [65]. Thus, more studies on the mechanism of crude extract and compounds isolated from the plant on parasites are required to strongly exemplify the anti-parasitic activity.

\section{Hematinic activity}

Anemia is characterized by a reduction in red blood cells, hemoglobin, and hematocrit in peripheral blood that affects people of all ages. The incidence of anemia is higher due to poor nutrition, poverty, and malaria [87]. Oladiji et al. [12] evaluated the hematinic potential of $W$. indica root (aqueous extract) on Albino rats tended on iron sufficient and iron deficient feeds. They observed a significant increase in hemoglobin count, packed cell volume, red blood cells, liver body weight rate, and mean corpuscular hemoglobin. The oral administration of aqueous extract of leaf increased the count of red blood cells, white blood cells, and the values of alanine and aspartate aminotransferase, creatinine, and blood urea nitrogen in male albino rats [88]. The increase in white blood cells is to defend microbial infection that may be linked to the anti-microbial activity of cardiac glycosides in the leaves. Hence, the anti-anemic property of the plant is reported, yet more detailed mechanism has to be evaluated to prove its traditional use.

\section{Aphrodisiac activity}

Aphrodisiacs are substances that stimulate sexual desire in humans. Male impotence affects the sexual life of millions of men worldwide. There was a growing need to search for herbal or natural plant aphrodisiacs with fewer side effects. The aqueous root extract of $W$. indica showed a dose-dependent increase in mounting frequency, intromission frequency, anogenital sniffing, and genital grooming, and a decrease in mount latency and intromission frequency as compared to control sildenafil citrate in male Wistar albino rats $[13,46]$. Though the aphrodisiac activity of the plant is studied, the area is open for more investigation in the mechanism of action and targets of the plant extracts/compounds.

\section{Anti-diabetic activity}

Diabetes mellitus is a metabolic disorder of carbohydrates, fat, and protein metabolism that leads to insulin deficiency, insulin resistance, and hyperglycemia [89]. In alloxan-induced diabetic rats, the methanol extract of $W$. indica showed a dose-dependent decrease in blood sugar level at 4th, 7th, and 14th days of analysis [11]. The hydro alcoholic root extract $(250 \mathrm{mg} / \mathrm{kg}, 500 \mathrm{mg} / \mathrm{kg}$ ) showed a significant reduction in the hyperglycemic peak in glucose $(2 \mathrm{~g} / \mathrm{kg})$ administered rats that was comparable to the effect detected with metformin. The regulation of blood glucose level is correlated with the presence of flavonoids and total phenols in plant extracts [90]. Thus, the study shows evidence for the traditional use of plants to cure diabetes. Detailed pharmacological studies on diabetic animal models, toxicological studies, and elucidation of active constituents present in the plant extracts are still required to understand the utility of these plants to control diabetes.

\section{Anti-cataract potential}

Formation of a visual lens cataract leads to difficulty in seeing for the majority of visually impaired individuals. For the oxidative stress-mediated age-related eye ailments; medications with prophylactic or cataract healing impacts are lacking. Rats actuated with naphthalene cataract were treated with $W$. indica ethanolic leaf extract that restored superoxide Dismutase (SOD), malondialdehyde (MDA), catalase, and glutathione $\mathrm{S}$ transferase to normal levels; also, it delayed the cataract onset and progression. The plant is also found to treat ophthalmia, conjunctivitis, and night blindness [15, 34]. Maintenance in the activity of antioxidant enzymes, decreased MDA levels, or retardation of sulfhydryl groups in lens epithelium might be responsible for plant anticataract function [10]. Still, molecular studies to 
understand the mechanism of anti-cataractogenic potential of the $W$. indica have to be analyzed and extended.

\section{Antioxidant activity}

Free radicals like reactive nitrogen, oxygen, and chlorine species are produced from various harmful chemicals, biochemical reactions, unhealthy foods, and stress. Hyperglycemic condition is also linked with the oxidative and nitrosative stress that induces tissue damage, over production of superoxide, lipid membrane oxidation, and DNA damage. This oxidative stress leads to the development of cardiovascular and neurological disorders. Mongalo et al. [37] showed antioxidant activity of methanol extract of $W$. indica roots at a concentration of $65.71 \pm 2.32 \mathrm{mg} / 100 \mathrm{ml}$ by inhibiting 2,2-diphenyl-1-picrylhydrazyl (DPPH). The aqueous leaf extract also inhibited in vitro lipid peroxidation in rat liver homogenate [9]. DPPH inhibition was dose-dependent in liver and kidney tissues of alloxan-induced diabetic rats when treated with methanolic extract of the whole plant [11]. Garba et al. [77] analyzed that $1.0 \mathrm{mg} / \mathrm{mL}$ of hexane leaves extract had $92.8 \%$ antioxidant activity higher than ascorbic acid and $\alpha$-tocopherol that had $90.2 \%$ and $15.4 \%$, respectively. Hydro alcoholic root extract inhibited hemolysis of erythrocytes induced by 2, 2'-azobis 2 amidino propane dihydrochloride (AAPH) dosedependently. The reducing power of the extract inhibited the production of nitric oxide thus exhibiting antioxidant property [90]. The phenolic compounds specifically the flavonoids and tannins present in the plant extract act as free radical scavengers that corresponds to the antioxidant potential of the plant.

\section{Anti-cancer activity}

There was an exponential increase in cancer that is caused by long-term exposure to mutagens or certain viral proteins. Phytochemicals are found to resist the invasion of these viral agents and inhibit the activity of viral oncoproteins [91]. The root, leaf, and branch extracts of $W$. americana were used for cancer treatment $[20,92]$. Nuclear factor- $\kappa B(\mathrm{NF}-\kappa \mathrm{B})$ induces inflam mation-mediated cancer promotion and progression. Monteillier et al. [14] isolated Waltheriones A and C from the decoction of the aerial parts of $W$. indica and confirmed their ability to induce phase 2 enzyme activity in Quinone reductase induction assay and NF- $\mathrm{kB}$ inhibition. Thus, the plant compounds offer interest in the field of cancer chemoprevention, yet the research against various cancer targets has to be explored and expanded.

\section{Other biological activities}

The aqueous extracts of root, stem, and leaves of $W$. indica had an intraperitoneal lethal dose $\left(\mathrm{LD}_{50}\right)$ of 69 $\mathrm{mg} / \mathrm{kg}, 363 \mathrm{mg} / \mathrm{kg}$, and $141 \mathrm{mg} / \mathrm{kg}$ body weight in mice
[46]. The aqueous ethanol extract from aerial parts showed $\mathrm{LD}_{50}$ of $875 \mathrm{mg} / \mathrm{kg}$ body weight in mice [72]. The cyclopeptide alkaloid, adouetin $\mathrm{Z}$ sulfonate also showed an intraperitoneal $\mathrm{LD}_{50}$ of $52.5 \mathrm{mg} / \mathrm{mL}$ in mice and a minimal lethal dose of $75 \mathrm{mg} / \mathrm{ml}$ [73]. The leaf extracts at high doses became hepatotoxic thus diffused hydropic degeneration of hepatocytes and induced cellular infiltration in the periportal region of the liver [88]. Though toxicity data and its related effects for specific organs are least available, the plant at high doses should be used with caution especially during pregnancy $[62,93,94]$.

\section{Patented products from $W$. indica}

Herbal compositions containing the key ingredients of $W$. indica for various applications have been patented. Some of the patented products include acne-removing cleanser [95], Cosmetic for skin whitening [96], lymphatic slimming [97], cosmetic preparation [98], and topical application [99].

\section{Conclusion}

Recently, medicinal plants are found to be the reservoir of secondary metabolites, and phytotherapy has attained a new era as natural drugs. This study emphasizes information on the current state of the art on W. indica, a medicinal plant used in several ethnomedical treatments. The phytoconstituents in each part of the plant is widely explored and related to the biological activities they execute. The pharmacological studies such as antiinflammatory, analgesic, sedative, anti-microbial, and anti-viral are extensively studied while the anti-cataract, anti-diabetics, asthma, anti-anemic, aphrodisiac, and anti-cancer activity have to be investigated more to identify the phytochemical attributing to the property and the mechanism of action in drug design and development. The study of diversity of endophytes in the proposed plant and the synthesis of silver nanoparticles from them are under progress. Also, the efficacy of synthesized nanoparticles as anti-cancer agent is under study to expand the pharmacological potency of the plant. Thus, the study will be a promotion for the development and expansion of plant-based medicine by conscious exploitation of biodiversity.

\section{Abbreviations \\ TNF: Tumor necrosis factor; PDE4A1: Phosphodiesterase-4A1; NF-kB: Nuclear factor kappa-light-chain-enhancer of activated B cells; GABA: Gamma aminobutyric acid; MIC: Minimal inhibition concentration; HIV: Human immunodeficiency virus; $I_{50}$ : Half maximal inhibitory concentration; SOD: Superoxide dismutase; DPPH: 2,2-diphenyl-1-picrylhydrazyl; AAPH: 2,2'- azobis 2 amidino propane dihydrochloride}

Acknowledgements

We gratefully acknowledge Vinayaka Missions Research Foundation (Deemed to be University), Salem for the support to carry out the literature search for research in the Waltheria indica. 


\section{Plant authentication}

The plant material was authenticated at Botanical Survey of India, Southern Regional Centre, Coimbatore with identification no. BSI/SRC/5/23/2020/ $\mathrm{TECH} / 562$.

\section{Authors' contributions}

CN had collected all the study material, analyzed, and prepared the complete manuscript. MS has critically reviewed the article for improvement. All authors have read and approved the final manuscript.

\section{Funding}

Not applicable

\section{Availability of data and materials}

All data generated or analyzed during this study are included in this article.

\section{Ethics approval and consent to participate}

Not applicable

\section{Consent for publication}

Not applicable

\section{Competing interests}

The authors declare that they have no competing interests.

\section{Received: 9 October 2020 Accepted: 28 December 2020}

Published online: 09 January 2021

\section{References}

1. McFarland B, Bigelow D, Zani B, Newsom J, Kaplan M (2002) Complementary and alternative medicine use in Canada and the United States. Am J Public Health 92(10):1616-1618. https://doi.org/10.2105/AJPH. 92.10.1616

2. Sardi JC, Scorzoni L, Bernardi T, Fusco-Almeida AM, Giannini MM (2013) Candida species: current epidemiology, pathogenicity, biofilm formation, natural antifungal products and new therapeutic options. J Med Microbiol 62(1):10-24. https://doi.org/10.1099/JMM.0.045054-0

3. Cragg GM, Newman DJ (2002) Drugs from nature: past achievements, future prospects. In: Advances in Phytomedicine 1. Elsevier, pp 23-37. https://doi. org/10.1016/S1572-557x(02)80010-1

4. Ledford H (2019) World's largest plant survey reveals alarming extinction rate. Nature 570(7760):148

5. Srithi K, Balslev H, Wangpakapattanawong P, Srisanga P, Trisonthi C (2009) Medicinal plant knowledge and its erosion among the mien (Yao) in northern Thailand. J Ethnopharmacol 123(2):335-342. https://doi.org/10. 1016/J.JEP.2009.02.035

6. Zongo F, Ribuot C, Boumendjel A, Guissou I (2014) Bioguidage search of active compounds from Waltheria indica L. (Malvaceae) used for asthma and inflammation treatment in Burkina Faso. Fundam Clin Pharmacol 28(3): 323-330. https://doi.org/10.1111/fcp.12037

7. Mathabe MC, Nikolova RV, Lall N, Nyazema NZ (2006) Antibacterial activities of medicinal plants used for the treatment of diarrhoea in Limpopo Province, South Africa. J Ethnopharmacol 105(1-2):286-293. https://doi.org/ 10.1016/J.JEP.2006.01.029

8. Olajuyigbe $\mathrm{OO}$, Babalola AE, Afolayan AJ (2011) Antibacterial and phytochemical screening of crude ethanolic extracts of Waltheria indica Linn. Afr J Microbiol Res 5(22):3760-3764. https://doi.org/10.5897/AJMR11. 627

9. Yougbare-Ziebrou MN, Lompo M, Ouedraogo N, Yaro B, Guissoun IP (2016) Antioxidant, analgesic and anti-inflammatory activities of the leafy stems of Waltheria indica L.(Sterculiaceae). J Appl Pharmaceutical Sci 6(02):124-129. https://doi.org/10.7324/JAPS.2016.60219

10. Atif M, Azharuddin M, Rahman SA, Ahmed MI, Mahmood SB (2014) Evaluation of anticataract potential of Waltheria indica in albino rats. Asian J Plant Sci Res 4(6):52-58

11. Kannan M, Kumar TS, Rao MV (2016) Antidiabetic and antioxidant properties of Waltheria indica L., an ethnomedicinal plant. Int J Pharma Res Health Sci 4(5):1376-1384. https://doi.org/10.21276/ijprhs.2020.02.04

12. Oladiji AT, Abdullahi SA, Yakubu MT (2005) Evaluation of haematinic potential of aqueous extract of Waltheria indica $L$ root on rats reared on iron sufficient and iron deficient feeds. Nig J Biochem Mol Biol 20(2):115122

13. Baskaran K, Ranjani R (2016) Aphrodisiac activity of aqueous root extract of Waltheria indica in male Wistar albino rats. Int J Pharmacol Res 6(2):141-143

14. Monteillier A, Cretton S, Ciclet O, Marcourt L, Ebrahimi SN, Christen P, Cuendet M (2017) Cancer chemopreventive activity of compounds isolated from Waltheria indica. J Ethnopharmacol 203:214-225. https://doi.org/10. 1016/j.jep.2017.03.048

15. Kokwaro JO (1976) Medicinal plants of East Africa. East African literature bureau

16. Traoré D (1983) Médecine et magie africaines: ou comment le noir se soigne-t-il?

17. Verdoorn IC (1981) The genus Waltheria in southern Africa. Bothalia. 13(3/4): 275-276. https://doi.org/10.4102/abc.v13i3/4.1316

18. Neal MC (1965) In gardens of Hawaii No. 581.9969 N342 1965

19. Abbott IA, Shimazu C (1985) The geographic origin of the plants most commonly used for medicine by Hawaiians. J Ethnopharmacol 14(2-3):213222. https://doi.org/10.1016/0378-8741(85)90089-3

20. Dimayuga RE, Murillo RF, Pantoja ML (1987) Traditional medicine of Baja California Sur (Mexico) II. J Ethnopharmacol 20(3):209-222

21. Dick C (2001) Amazon plant list. Ecotour Expeditions, Inc http://www. naturetours.com/Am lispl.html, p 8

22. Nelson G (1996) The shrubs and woody vines of Florida: a reference and field guide. Pineapple Press Inc. Sarasota, http://www.pineapplepress.com. ISBN:1-56164-106-5.

23. Texas A (2001) M University. Texas vascular plant checklist: Sterculiaceae. Texas A \& M University, Department of Botany. http://www.csdl.tamu.edu/ FLORA/ftc/dft/ftc_str.htm, p 1

24. Sharma SC, Goel AK (1991) Potential of Indian wild plants as ornamentals. InHorticulture-new technologies and applications. Springer, Dordrecht, pp 379-382. https://doi.org/10.1007/978-94-011-3176-6_60.

25. Harihar NS (2014) Plant diversity status in the scrub forest of Kappath hills Gadag district Karnataka

26. Gandhi SM, Aswathanarayana U (1975) A possible base-metal indicator plant from Mamandur, South India. J Geochem Explor 4(2):247-250. https:// doi.org/10.1016/0375-6742(75)90004-7

27. Saunders JG (2007) Sterculiaceae of Paraguay. II. Waltheria. Bonplandia 16: 143-180

28. Fosberg FR, Sachet MH (1975) Polynesian plant studies 1-5. Smithsonian contributions to botany

29. Zongo F, Ribuot C, Boumendjel A, Guissou I (2013) Botany, traditional uses, phytochemistry and pharmacology of Waltheria indica L. (syn. Waltheria americana): a review. J Ethnopharmacol 148(1):14-26. https://doi.org/10. 1016/j.jep.2013.03.080

30. Burkill HM (1985) The useful plants of west tropical Africa. Vol. 1 Families AD. Royal botanic gardens

31. Vattakaven T, George RM, Balasubramanian D, Réjou-Méchain M, Muthusankar G, Ramesh BR, Prabhakar R (2016) India biodiversity portal: an integrated, interactive and participatory biodiversity informatics platform. Biodiversity Data J 4. https://doi.org/10.3897/BDJ.4.e10279

32. Hutchinson J, Dalziel JM (1954) Flora of west tropical Africa. Flora West Tropical Africa 2. Edn 2 pp.137

33. Irvine FR (1961) Woody plants of Ghana. Woody plants of Ghana

34. Kerharo J, Adam JG (1974) La pharmacopée sénégalaise traditionnelle: plantes médicinales et toxiques

35. Sita G (1978) Traitement traditionnel de quelques maladies en pays Bissa (République de haute-Volta). Bull Agricole du Rwanda 11:24-34

36. Nacoulma OG (1996) Plantes médicinales et pratiques médicales traditionnelles au Burkina Faso: cas du plateau centralFaculté des Sciences et Techniques, Université de Ouagadougou, p 320

37. Mongalo NI, Opoku AR, Zobolo AM (2012) Antibacterial and antioxidant activity of the extracts of Waltheria indica Linn. Collected from, Capricorn District, Limpopo Province, South Africa. J Med Plant Res 6(43):5593-5598. https://doi.org/10.5897/AJB2013.12321

38. Aguilar NO, van Valkenburg $\mathrm{L}$ (2001) Waltheria indica L. In: In medicinal and poisonous plants 2 Backhuys publishers 585-587

39. Scheuer PJ, Horigan LP, Hudgins WR (1962) A survey for alkaloids in Hawaiian plants, III

40. USDA (2010) ARS, National Genetic Resources Program. Germplasm resources information network (GRIN)

41. Tropical Plants Database, Ken Fern. tropical.theferns.info. 2020-11-22 tropical.theferns.info/viewtropical.php?id=Waltheria+indica 
42. Sasidharan, N. (Dr. B P Pal Fellow), Kerala Forest Research Institute, Peechi.

43. Borokini Tl, Omotayo FO (2012) Phytochemical and ethnobotanical study of some selected medicinal plants from Nigeria. J Med Plant Res 6(7):11061108. https://doi.org/10.5897/JMPR09.430

44. Dalziel JM (1937) The useful plants of west tropical Africa. In: The useful plants of west tropical Africa

45. Loustalot AJ, Pagan C (1949) Local "fever" plants tested for presence of alkaloids. El Crisol 3(5):3

46. Mohammed Z, Shok M, llyas N, Musa KY, Yaro AH (2005) Analgesic activity of Waltheria indica Linn. Editorial Advisory Board 16(1):6-9

47. Zailani AH, Jada SM, Wurochekke UA (2010) Antimicrobial activity of Waltheria indica. J Am Sci 6(12):1591-1594

48. Gbadamosi IT, Moody JO, Yekini AO (2012) Nutritional composition of ten ethnobotanicals used for the treatment of anaemia in Southwest Nigeria. Eur J Medicinal Plants:140-150. https://doi.org/10.9734/EJMP/2012/1025

49. Basiru A, Soetan K, Olayemi FO (2016) Comparative proximate, minerals composition and antinutritional factors of Waltheria indica leave, root and stem. Annals. Food Sci Technol 17(2):478-484

50. Koma OS, Fatokun OA, Theophilus OA (2017) Phytochemical screening and in vitro antimicrobial activity of Waltheria indica Linn leaf extracts. Biomed Sci 3(5):86

51. Petrus AJ (1990) Polyphenolic components of Waltheria indica. Fitoterapia 61(4):371

52. Cretton S, Dorsaz S, Azzollini A, Favre-Godal Q, Marcourt L, Ebrahimi SN, Voinesco F, Michellod E, Sanglard D, Gindro K, Wolfender JL (2016) Antifungal quinoline alkaloids from Waltheria indica. J Nat Prod 79(2):300307. https://doi.org/10.1021/acs.jnatprod.5b00896

53. Watt JM, Breyer-Brandwijk MG (1962) The medicinal and poisonous plants of southern and eastern africa being an account of their medicinal and other uses, chemical composition, pharmacological effects and toxicology in man and animal. In: The medicinal and poisonous plants of southern and eastern Africa being an account of their medicinal and other uses, chemical composition, pharmacological effects and toxicology in man and animal Edn 2

54. Païs M, Mainil J, Goutarel R (1963) The adouetins X, Y and Z, alkaloids of Waltheria americanan L.(Sterculia). Annales pharmaceutiques francaises 21: 139-146

55. Païs M, Marchand J, Jarreau FX, Goutarel R (1968) Alcaloïdes peptidiques. V. -structures des adouétines $X, Y, Y 1$ et $Z$, alcaloïdes du Waltheria americana $L$. (Sterculiacées) [Reptide alkaloids. V. Structures of adouetines $X, Y, Y 1$, and $Z$, the alkaloids of Waltheria americana L. (Sterculiaceae)]. Bull Soc Chim Fr 3:1145-1148

56. Rao YK, Fang SH, Tzeng YM (2005) Inhibitory effects of the flavonoids isolated from Waltheria indica on the production of NO, TNF-a and IL-12 in activated macrophages. Biol Pharm Bull 28(5):912-915. https://doi.org/10. 1248/bpb.28.912

57. Maheswara M, Rao YK, Rao VM, Rao CV (2006) Antibacterial activity of acylated flavonol glycoside from Waltheria indica. Asian J Chem 18(4):2761

58. Musa Y, Musah M, Yerima H, Erena NB (2016) Study of phytochemical and antimicrobial activities of Waltheria indica. J Adv Res Appl Sci (ISSN: 22082352) 3(4):30-39

59. Ragasa CY, Cruz CA, Chiong ID, Tada M, Rideout JA (1997) Antifungal flavonoids from Waltheria americana. Philippine journal of science (Philippines)

60. Banakar P, Jayaraj M (2018) GC-MS analysis of bioactive compounds from ethanolic leaf extract of Waltheria indica Linn. And their pharmacological activities. Int J Pharm Sci Res 9(5):2005-2010. https://doi.org/10.13040/IJPSR. 0975-8232.9(5).2005-10

61. Cretton S, Breant L, Pourrez L, Ambuehl C, Marcourt L, Ebrahimi SN, Hamburger M, Perozzo R, Karimou S, Kaiser M, Cuendet M (2014) Antitrypanosomal quinoline alkaloids from the roots of Waltheria indica. J Nat Prod 77(10):2304-2311. https://doi.org/10.1021/np5006554

62. Leonard DB (2010) Medicine at your feet: healing plants of the Hawaiian kingdom. Roast Duck Producktions, US, p 1. Roast Duck Producktions, 2012. ISBN 10: 0980050529 ISBN 13: 9780980050523.

63. Jansen $O$, Angenot L, Tits M, Nicolas JP, De Mol P, Sacré PY, Jonville MC, Frederich M (2008) In vitro antiplasmodial activity of ethnobotanically selected plants from Burkina Faso. Planta Med 74(09):PF14. https://doi.org/10.1055/s-0028-1084742

64. Wagner WL, Herbst DR, Sohmer SH (1999) Manual of the flowering plants of Hawai'i, Vols. 1 and 2. 1999 No.Edn 2 pp.xviii + 1919. University of Hawai'i and Bishop Museum Press, Honolulu

65. Bala AY, Adamu T, Abubakar U, Ladan MJ (2011) Inhibition of Trypanosoma brucei brucei by extracts from Waltheria indica L.(sleepy morning). Res J Parasitol 6:53-59
66. Vardhana R (2008) Direct uses of medicinal plants and their identification. In: Sarup \& sons

67. Khare CP (2008) Indian medicinal plants: an illustrated dictionary. Springer Science \& Business Media, LLC, 233 Springer street, New York USA. ISBN:9780-387-70637-5

68. Graziani Y, Erikson E, Erikson RL (1983) The effect of quercetin on the phosphorylatio activity of the Rous sarcoma virus transforming gene product in vitro and in vivo. Eur J Biochem 135(3):583-589. https://doi.org/ 10.1111/j.1432-1033.1983.tb07692.x

69. Vedavathy S, Narayana Rao K (1995) Anti-inflammatory activity of some indegenous medicinal plants of Chittoor District, Andhra Pradesh. Indian Drugs 32(9):427-432

70. Chandekar A, Vyas A, Upamanyu N, Tripathi A, Agarwal S (2017) Preliminary screening of Waltheria indica $(\mathrm{L})$ plant for its anti-inflammatory activity. Int J Phytomed 9:275-278

71. Owemidu IO, Olubori MA, Faborode OS, Oloyede OS, Onasanwo SA (2018) Anti-nociceptive and anti-inflammatory activities of the methanol extract of Waltheria americana Linn. Leaf in experimental animals. J Complement Med Res 9(2):47-54

72. Hamidu LJ, Ayo JO, Adelaiye AB, Abubakar MS (2008) Sedative and anticonvulsant effects of ethyl acetate fraction of Waltheria indica in mice. J Pharmacol Toxicol 3:261-266

73. Blanpin O, Pais M, Quevauviller MA (1963) Pharmacodynamic study of adouetin Z, alkaloid of Waltheria americana L.(Sterculia). Annales pharmaceutiques francaises 21:147

74. Igwebuike EV, Ahamefule OF, Obododike EC (2017) Standardization and evaluation of anticonvulsant activities of leaf extract and fractions of Waltheria indica (Baudilio) (Malvaceae). https://doi.org/10.21276/apjhs.2017.4. 2.10

75. Mundo J, Villeda-Hernández J, Herrera-Ruiz M, del Carmen Gutiérrez M, Arellano-García J, León-Rivera I, Perea-Arango I (2017) Neuropharmacological and neuroprotective activities of some metabolites produced by cell suspension culture of Waltheria americana Linn. Biomed Pharmacother 94:129-139

76. Mundo J, Castillo-España P, Villafuerte MD, Camacho CA, León-Rivera I, Arellano-García J, Perea-Arango I (2015) Methanolic extracts from roots and cell suspension cultures of Waltheria americana Linn induce GABA release in cerebral slices of mouse brain. Afr J Pharm Pharmacol 9:139-144. https:// doi.org/10.5897/AJPP2014.4115

77. Garba S, Salihu L, Ahmed MU (2012) Antioxidant and antimicrobial activities of ethanol and n-hexane extracts of Waltheria indica and Mucuna pruriens. J Pharmaceutical Sci Innov 1(5):5-8

78. Mongalo NI (2014) Antibacterial activity of Waltheria indica Linn (Sterculiaceae), collected from Blouberg area, Limpopo Province, South Africa. Afr J Biotechnol 13(31). https://doi.org/10.5897/AJB2013.12321

79. Osman RE, Elnima El, Omer MEA (2013) Biological activity of methanolic extract of Waltheria indica roots. J Med Sci 13(6):471-476

80. Olakunle FA, Koma OS, Theophilus OA (2017) Phytochemical screening and in vitro antimicrobial activity of Waltheria indica Linn root extracts. Int J Biochem Biophys Mol Biol 2(6):71. https://doi.org/10.11648/j.j.jbbmb. 20170206.13

81. Koné WM, Atindehou KK (2008) Ethnobotanical inventory of medicinal plants used in traditional veterinary medicine in northern Côte d'Ivoire (West Africa). S Afr J Bot 74(1):76-84. https://doi.org/10.1016/j.sajb.2007.08.015

82. Cretton S, Bréant L, Pourrez L, Ambuehl C, Perozzo R, Marcourt L, Kaiser M, Cuendet M, Christen P (2015) Chemical constituents from Waltheria indica exert in vitro activity against Trypanosoma brucei and T. cruzi. Fitoterapia 105:55-60. https://doi.org/10.1016/j.fitote.2015.06.007

83. Loaiza Gutiérrez VL (2014) Análisis del efecto antiviral de Waltheria americana L (Standley y Steyermarl, 1949) en el proceso infectivo de rotavirus humano sobre células MA 104 (doctoral dissertation, Universidad Autónoma de Nuevo León)

84. Miyashiro H, Lim JA, Nakabayashi T, Miyaji M, Hattori M, Shimotohno K (1994) Inhibitory effects of tropical plants on HIV-protease. Int Conference AIDS 10:112

85. Maregesi SM, Pieters L, Ngassapa OD, Apers S, Vingerhoets R, Cos P, Berghe DA, Vlietinck AJ (2008) Screening of some Tanzanian medicinal plants from Bunda district for antibacterial, antifungal and antiviral activities. J Ethnopharmacol 119(1):58-66. https://doi.org/10.1016/j.jep.2008.05.033

86. Maregesi S, Van Miert S, Pannecouque C, Haddad MH, Hermans N, Wright CW, Vlietinck AJ, Apers S, Pieters L (2010) Screening of Tanzanian medicinal 
plants against Plasmodium falciparum and human immunodeficiency virus. Planta Med 76(02):195-201. https://doi.org/10.1055/s-0029-1186024

87. Asuquo RO, Ekanem BT, Udoh BP, Mesembe EO, Ebong EP (2013) Haematinic potential of Spondias mombin leaf extract in Wistar rats. Adv Biores 4(2):53-56

88. Basiru A, Olayemi FO (2014) Effects of aqueous extract of Waltheria indica leaves on blood profile of male albino rats. J Med Plant Res 8(41):12231229. https://doi.org/10.5897/JMPR2014.5477

89. Sharma RK, Patki PS (2010) Double-blind, placebo-controlled clinical evaluation of an Ayurvedic formulation (GlucoCare capsules) in non-insulin dependent diabetes mellitus. J Ayurveda Integr Med 1(1):45. https://doi.org/ 10.4103/0975-9476.59827

90. Povi LE, Batomayena B, Hodé TA, Kwashie EG, Kodjo A, Messanvi G (2015) Phytochemical screening, antioxidant and hypoglycemic activity of Coccoloba uvifera leaves and Waltheria indica roots extracts. Int J Pharm Pharm Sci 7(5):279-283

91. Nirmala C, Banerjee S, Sridevi M, Rajeshwari R (2019) Molecular docking study of apigenin-7-O- $\beta$-D-glucuronide with viral oncoproteins. American international journal of research in science, technology, Engineering \& Mathematics. National Conference on innovations in bio-chemical and. FoodTechnol 094.241-249

92. Graham JG, Quinn ML, Fabricant DS, Farnsworth NR (2000) Plants used against cancer-an extension of the work of Jonathan Hartwell. J Ethnopharmacol 73(3):347-377. https://doi.org/10.1016/s0378$8741(00) 00341-x$

93. Hodge HC, Sterner JH (1943) Determination of substance acute toxicity by LD50. Am Ind Hyg Assoc 10:93

94. IPCS (2002) The WHO recommended classification of pesticides by hazard and guidelines to classification 2000-2002. IOMC, WHO/PCS/ 015 58:2-14

95. Wilmott JM, Aust DT, Crawford TK (2004) inventors; Lab21 Inc, assignee. Method for producing customized cosmetic and pharmaceutical formulations on demand. United States patent US 6,782,307 Aug 24

96. Moussou P, Danoux L, Bailly L, Gillon V, inventors; Cognis IP (2018) Management $\mathrm{GmbH}$, assignee. Cosmetic composition comprising a combination of a sugar fatty acid ester with a plant extract of Waltheria indica or Pisum sativum for skin whitening United States patent US 9,949,917 Apr 24

97. Shinkawa S (2014) inventor. Method and external preparation for lymphatic slimming. United States patent application US 13/798,984 Mar 27.

98. Pauly M, Moser P, Gillon V (2003) inventors; BASF Health, Care Products France SAS, assignee. Cosmetic preparations containing Waltheria indica extracts. United States patent application US 10/203,228 Aug 14

99. Wirth C, Buchholz H, Costa AA (2008) inventors; Merck Patent GmbH, assignee. Extraction method for producing plant extracts, especially Waltheria Paniculata extracts containing tiliroside. United States patent application US 11/909,348 Aug 14.

\section{Publisher's Note}

Springer Nature remains neutral with regard to jurisdictional claims in published maps and institutional affiliations.

\section{Submit your manuscript to a SpringerOpen ${ }^{\circ}$ journal and benefit from:}

- Convenient online submission

- Rigorous peer review

- Open access: articles freely available online

- High visibility within the field

- Retaining the copyright to your article

Submit your next manuscript at $\boldsymbol{\nabla}$ springeropen.com 